\title{
Analysing Inference
}

\author{
And Ethos-Implicature in Particular
}

\author{
THORE ROKSVOLD
}

\begin{abstract}
In the article "Analyse inference - and ethos-implicature in particular" I discuss and define the notions of inference, presuppositions, premises and implicature as notions of what sort of information texts carry between the lines, i.e. beneath the surface level. Through this discussion I hope and think it may be possible to use the notions more precisely. By way of clarifying the concept I find it appropriate to distinguish between statistical, semantic, logical and pragmatic inference. I especially focus how inferred information contributes to the constitution of the author's ethos. As an example, I analyse (and criticise) ethos-implicature in a commentary article in a Norwegian newspaper. Tools for the analysis are both from argumentation theory and stylistics.
\end{abstract}

Key Words: inference, implicature, presupposition, ethos, rhetoric, argumentation, stylistics, semantics, pragmatics

\section{Introduction}

Put simply, inference denotes that there is something that exists between the lines, something one is able to deduce. Both text and context work together when we deduce an inference. In this rhetorical analysis I focus in particular on how the credibility of what has been put down in the text is also part of the inference. What picture of himself does the writer reveal between the lines of the text? Moreover, how can we analyse this picture? Finally, I demonstrate this with a table that lays out the analysis of the text I use as an example.

I have chosen as my object of analysis a commentary article by the Norwegian editor/columnist Per Egil Hegge. This article appeared in the newspaper Aftenposten on February 13, 2004. Aftenposten is published in Oslo and is Norway's largest subscription newspaper. The article is called "Fat Pork behind Closed Doors" and is a commentary on the Norwegian Language Council (which is a publicly appointed body charged with regulating the Norwegian language) on that particular day when it was about to implement its proposal for the Norwegian spelling of English words frequently used in the Norwegian language. Hegge is known to have a conservative outlook on language. He is particularly preoccupied with incorrect word use and faulty syntax, and feels that these areas indicate clear signs of language breakdown. In light of this, he finds immaterial the fact that philologists, working from the perspective of language politics, are 
concerned with the manner in which words are spelled, as are the members of the Norwegian Language Council, where university-trained linguistics professors have distinguished themselves through the vehemence of their arguments in the debate about spelling. What is special about language politics in Norway is that the way of speaking of the average Norwegian has a higher status than does spoken language in most other countries. Consequently, this small country has two authorized written Norwegian languages and great variety within each of them.

Newspaper commentaries are traditionally written by editorial colleagues who have special insights into, and background knowledge of, the themes on which they comment. A newspaper commentary should be a competent and enlightening contribution to the social debate. The genre is discursive and argumentative.

The label "commentary" in this example article therefore signals and creates the expectation that we are about to take part in an insightful and fundamental point of view about aspects of the Norwegian Language Council's annual general meeting. At the same time, the demand for documentation is not as strongly enforced in commentary journalism as it is in scholarly and scientific writing. Documentation in commentary articles is often found in news articles about the same theme.

I have often been struck by the fact that Hegge is somewhat cavalier when it comes to documentation in his articles. He confines himself to assertions, and these have a sarcastic sting that gives him authority as a writer. Thus, for many readers, he is considered to be a commentator worth reading. It is this relationship that I have wished to analyse for some time. Accordingly, I am interested in commentary as a genre and in Hegge's authority as a commentary writer. Thus, I use the chosen text as an example for analysis. The question is: what kind of picture of himself does Hegge present - between the lines - that gives him this authority, when the documentation has been treated so loosely? Moreover, how can one develop a procedure to analyse such authority-building by inference? In other words, on what does the commentary writer base his attitude, and how does he try to instil confidence and present himself as credible?

In other commentary articles, and in texts written in genres other than this, the writer's authority can certainly be constructed by other means - or the same means can be used differently. But the categories of inference function in a rather universal manner. Moreover, as I have previously used the approach of tabulating the analysis of the example text - on that occasion a news report (Roksvold 2003: 196ff) - I consider that the analysis I am demonstrating can be used to examine authority-building by inference in other texts and genres as well.

The analysed text is appended to this article. I have dealt with it thematically in sections numbered 1-17, which are used both by way of exemplification and in the analytical table. All the examples are taken from Hegge's text.

\section{The Types of Evidence in Rhetoric}

The concept of ethos in rhetoric can be used in the analysis of authority-building in a text.

Aristotle (Hastrup 1991) divided professional means of evidence into three types, which can be linked to three fundamental aspects of a communications model: the speaker, the listener and the text. The first professional type of evidence is called ethos, the second, pathos, and the third, logos. Trust and credibility - the authority of the speaker/writer - are linked to the rhetorical category ethos.

Thure Hastrup translates ethos as "character" and renders Aristotle as follows: 
Conviction is created by means of the speaker's character (ethos), when the speech is given in such a way, that it makes the speaker's person credible. That is, we believe more and with greater willingness what decent people say, and this generally applies to all situations, but, wherever there is no certainty and room for doubt remains, credibility is entirely determined this way (Hastrup 1991: 34).

Thus ethos is especially important in places that are beyond the reach of logos - as in commentary articles with weak documentation. On the other hand, a person's ethos is strengthened when he/she is perceived to be truthful. Following logos as far as possible strengthens a person's ethos. This is consistent with the quality maxim of the American communications researcher $\mathrm{H}$. Paul Grice regarding communicative cooperation: "Do not say what you believe to be false. Do not say that for which you lack adequate evidence" (Grice 1975: 46).

There is a more durable evidentiary power in logos and ethos than in pathos. Logos pertains until the evidence is refuted logically. Ethos pertains as long as the writer is not exposed as dishonest or untrustworthy and thereby loses trust. Pathos arguments are supported by evidence that awakens feelings such as indignation, compassion, sorrow, joy, hate, contempt, envy, desire, disappointment, anger, rapture and so forth. Whereas pathos is perhaps the strongest momentary evidentiary basis, it is also the one that is easiest to refute. It appeals to the malicious pleasure of, in particular, uneducated journalists who maintain - as in Section 13 of the example article - that newly educated journalists "have only this one question as mental baggage, 'What's the big deal?"'. This assertion can be regarded as humorous, but it does not hold as a critical reflection.

Quintillian replaces pathos with "affectus" (Lindhardt 1987: 88), and pathos arguments do arouse affect - by means of exaggeration, bold assertions and tropes that create associations and emotions. Simplifications are frequently raised. Issues are not presented in all their complexity. One chooses and focuses on those aspects that can create the affects one desires. In pathos rhetoric, facts are either presented piecemeal, in a distorted fashion, or both. Anders Sigrell (2001: 155-158) distinguishes between proving and persuading. Proving is the end-product of a cognitive process. The results go deeper and are more comprehensive than what happens with persuasion. Logos arguments aim to convince; pathos arguments are suited to persuasion.

\section{The Means of Inference of Enthymemes}

According to Jørgen Fafner (1982: 63), Aristotle regarded speech particularly as logos and devised the system of circumstantiation, which we recognize from logic as syllogisms where durable arguments can be formed as valid relations between two true premises and a conclusion.

At the same time, we do not speak in syllogisms. That would break with Grice's quantity maxim: "Make your contribution as informative as is required (for the current purpose of exchange). Do not make your contribution more informative than is required" (Grice 1975: 45). When we speak (and write), we imply the parts of argumentation that we ourselves take as given and that we also assume our discussion partner takes as given. In this situation, that which is implied is redundant. The result would be ineffective communication if, on every occasion, we had to establish all the factors that our reasoning was built upon. Thus, we speak in what Aristotle called enthymemes, which are explained as incomplete syllogisms. The major premise, the minor premise or the conclusion may be omitted. 


\section{Deduction}

The method of inference, in which we conclude on the basis of a major premise ('propositio major') and a minor premise ('propositio minor'), is called deduction. We conclude something about a specific instance in the minor premise against the background of a common proposition in the major premise of which the specific instance is an example. This is the only method of inference that is beyond discussion:

- Major premise: *All those who have a good grasp of Southern Europe are aware that the Norwegian Language Council's members are appointed on the basis of ideas that Benito Mussolini used to found the corporative state.

- Minor premise: Sylfest Lomheim has a good grasp of Southern Europe.

- Conclusion: Sylfest Lomheim knows that the Norwegian Language Council's members are appointed on the basis of ideas that Benito Mussolini used to found the corporative state.

(See Section 14, the example article)

Given that the major premise and the minor premise are true, the conclusion is the only one possible. In Section 14 of the example article, the major premise must be implied (marked here with “*”). The truthfulness does not hold up in the face of critical contemplation if this major premise is made explicit. This may be the reason why it is not made explicit. In the text, the minor premise is made probable by the parenthetic clause "(the man is a Francophile)". This information substantiates the commentary writer's ethos: the commentary writer is well-informed.

\section{Induction}

The method of inference changes if the relationship between the major premise, the minor premise and the conclusion is changed. In such cases, we get an inference method that is less secure and therefore debatable. Charles S. Peirce called the common proposition the "rule" (Svennevig 2001a: 4). He called the specific instance the "case", and the conclusion in the deductive syllogism he called the "result" (ibid.). The method of inference called induction is to conclude a common proposition on the background of examples, individual cases or individual observations. Thus, with induction, the case is used as the major premise, the result as the minor premise and the rule as the conclusion:

- Case: Sylfest Lomheim has a good grasp of Southern Europe.

- Result: Sylfest Lomheim knows that the Norwegian Language Council's members are appointed on the basis of ideas that Benito Mussolini used to found the corporative state.

- Rule: *All those who have a good grasp of South Europe know that the Norwegian Language Council's members are appointed on the basis of ideas that Benito Mussolini used to found the corporative state.

Induction is a debatable method of inference. Even if Sylfest Lomheim himself has a good grasp of Southern Europe and knows that the Norwegian Language Council's members are appointed on the basis of ideas that Benito Mussolini used to found the corporative state, it is not therefore given that all who have a good grasp of Southern Europe know that the Norwegian Language Council's members are appointed on the 
basis of ideas that Benito Mussolini used to found the corporative state. Another issue is whether Lomheim knows that the Norwegian Language Council's members are appointed on the basis of the ideas that Benito Mussolini used to found the corporative state. Perhaps this is not something one can know? Perhaps it is not true?

An example of the inductive method of inference in the example article is found in Section 7-8:

- Case: Helge Sandøy is a linguistic researcher who quantifies.

- Result: *Helge Sandøy is uninterested in and not knowledgeable about good Norwegian.

- Rule: *All research linguists who quantify are uninterested in and not knowledgeable about good Norwegian.

Here both the "result" and the "rule" are implied (marked with "*”), perhaps because the truthfulness does not stand up to critical consideration. Generalizations, which are a type of fallacy or wrongful thinking (Pirie 1987), are normally the result of inductive conclusions.

Both deduction and induction are known from Aristotle's logic. In his book The Problem of Inference (1938), W. H. V. Reade refers to the concept "inference" as precisely the deductive and inductive methods of reaching a conclusion. When such inference involves logical methods of reaching a conclusion, we are dealing with what I will call logical inference. This refers to logical relations between sentences - accordingly in the text.

When one looks up inference in the BIBSYS database, one finds that most of the titles that come up have to do with statistical inference. Here the question is what one is able to conclude on the basis of numbers. Assessments of validity and representativity, tests for reliability and significance, as well as other calculations of probability express how securely one can make conclusions based on numerical data related to empirical material. If we are not talking about a total body of material, then such evaluations and expressions of measurement are brought to bear on partial materials, obtained by way of sampling or used as examples. When we arrive at generalized conclusions from examples, the method of inference is inductive. Statistical inference is an inductive method of arriving at a conclusion.

In Section 8 of the example article the commentary writer ridicules statistical inference. He asks how Sandøy has arrived at the number four - based on which data, which examples were chosen, and how? But the commentary writer's objections are not made concrete. Perhaps Sandøy has good grounds to maintain that the tempo of Norwegianization ought to be quadrupled? Maybe he has performed controlled calculations that make this number probable? This is something we do not get to know. The commentary writer simply takes for granted that the number has been plucked out of thin air, and that such calculations are impossible. Consequently, he does not substantiate his critique of Sandøy, but gambles on the belief that the public has the same attitude as he has, that language issues cannot be expressed numerically. For readers who at the outset share this perception, ridicule is sufficient argument. They confirm their mutual understanding as a pragmatic presupposition. I think such readers consider this point of view as truth and not as ideology, and they know that people of the same persuasion also consider it as such. Pragmatic presuppositions constitute knowledge of the world (in the philosophical sense) that is supposed to be common and therefore implied. For these 
readers, the commentary writer maintains his ethos by playing on prejudices. For readers who do not share the prejudice, he loses his ethos here precisely by refraining from substantiating his argument. Ridicule is a pathos argument. Ridicule also deprives others of their ethos. Sandøy has little in the way of ethos in the minds of readers who accept the commentary writer's prejudices.

\section{Abduction}

In addition to induction and deduction, Peirce introduced a third logical method of inference that he called "abduction" (Svennevig 2001a: 4). Here, specific instances are concluded on the basis of "rule" and "result":

- Rule: *All those who have a good grasp of Southern Europe know that the Norwegian Language Council's members are appointed on the basis of ideas that Benito Mussolini used to found the corporative state.

- Result: Sylfest Lomheim knows that the Norwegian Language Council's members are appointed on the basis of ideas that Benito Mussolini used to found the corporative state.

- Case: Sylfest Lomheim has a good grasp of Southern Europe.

This method of coming to a conclusion is also dubious: even if Sylfest Lomheim knows that the Norwegian Language Council's members are appointed on the basis of ideas that Benito Mussolini used to found the corporative state, this does not prove that he has a good grasp of Southern Europe. In a best-case scenario, this is only a hypothesis that can be investigated (op. cit.: 10, 17).

One example of abductive inference in the example article is found in the lead-in (Section 2) as well as in Section 11 and 12:

- Rule: *All professional circles that shut themselves away, because the real world becomes too hard and too difficult, and because they toil away with spelling, are odd, social anthropological isolates.

- Result: Norwegian philological circles constitute an odd social anthropological isolate.

- Case: Norwegian philological circles shut themselves away, because the real world becomes too hard and too difficult, and because they toil away with spelling.

Here the "rule" is implied. The reason for this is not exactly that the claim is controversial, because it is not. Rather, the question is whether such professional circles are to be found. And if they are not to be found, the argument is rather uninteresting.

Both induction and abduction can yield correct conclusions, but it is not certain that these methods of inference actually make them correct.

In argumentation that rests upon logos, both the major and the minor premises must be true or at least probable, and the conclusion must be valid. Argumentation that rests on ethos and pathos assumes only that the premises and the conclusion function persuasively for the public (Sandvik 1995: 251). Margareth Sandvik (op. cit.) relates deductive and inductive syllogisms to the logos category, while she relates enthymemes, which she calls rhetorical deductive syllogisms, to ethos. She links rhetorical inductive syllogisms, which she calls examples, with pathos. This works both rationally and demon- 
stratively, as examples can certainly be effective for arousing emotions. Thus, she relates syllogisms, enthymemes and examples, respectively, to logos, ethos and pathos. Abductive syllogisms are not part of Sandvik's overview.

\section{Implied Premises}

Therefore, when one is faced with exposing dubious argumentation, it can be particularly rewarding to investigate enthymemes and examples, where claims are based on implied premises and have to be reconstructed when one is evaluating the validity of the argumentation.

Sigrell refers to some implied premise-making as implicating argument (Sigrell 2001: 10). By this term he means enthymemes used where it is not evident that the speaker and the listener are in agreement that what is omitted is redundant in the sense that the content is self-evident and non-controversial: A persuasive effect can come about by means of communicating implied premises about which there is no prevailing agreement, pretending they are so self-evident that there is no need to express them in words (ibid.). In other words, implicating argument is that which runs the risk of challenge if the premise is not implied (op. cit.: 12). By means of such implied premises - precisely of the kind I have shown as examples from the article "Fat Pork behind Closed Doors" a logical analysis is capable of diminishing the speaker's ethos.

The basis for redundant implied premises usually lies in the process of verifying, realized by the speech act category called constatives (Searle 1969; Vagle et al. 1993:89); what Sigrell calls implicating implied premises are generally based on the speech act category of evaluations (Fabricius \& Roksvold 2004: 101ff).

I choose to call this latter type of implied premise "non-redundant" instead of implicating, as both redundant and non-redundant implied premises must indeed be viewed as "implicating".

In the example article (Sections 4 and 9), the major premise in the valid modus ponens argument (Sandvik 1995: 285) that follows, is a non-redundant implied premise:

- Major premise: *If a language council Norwegianizes the spelling of borrowed words, it ought to be closed down

- Minor premise: The Norwegian Language Council Norwegianizes the spelling of borrowed words

- Conclusion: The Norwegian Language Council ought to be closed down

It is dubious whether the major premise would be able to arrive at a common conclusion, therefore this is not redundant. Those who do not wish to be easily taken in by the argumentation of others must be aware of non-redundant implied premises.

Redundant implied premises behave differently. In the example article, the major premise in the following reconstructed syllogism is a redundant implied premise:

- Major premise: *All soup councils should be closed down

- Minor premise: The Norwegian Language Council is a soup council

- Conclusion: The Norwegian Language Council should be closed down

Nobody can be considered in disagreement with the statement that all soup councils should be closed down. The challenge in this argument is to achieve agreement upon the 
minor premise. To make the minor premise probable is on the surface the main task set by the example article. In the article, the minor premise is supported by contentions that the Norwegian Language Council proposes to Norwegianize the spelling of some borrowed words. But in the article we do not get to know what is wrong with this proposal. That it is wrong, and how it is wrong are non-redundant implied premises. Roland Barthes calls situations in which ideology has not been problematized naturalized (Barthes 1969: 165, 173). Naturalization and non-ideologization can thus be understood as non-redundant implied premises.

\section{Sub-categories of Inference}

In addition to statistical and logical inference, we have what I will call semantic and pragmatic inference. The reason that it can be useful to divide inference into these four sub-categories is that the terminology regarding messages between the lines can thereby be made more clearly. For example, what is the difference between presuppositions and implied premises?

Presuppositions are generally explained as background information for what is expressed (Svennevig 2001b: 51). According to Sigrell (2001: 8), presuppositions comprise common background knowledge that is not included in the argumentation. Sigrell (ibid.) distinguishes between presuppositions and implied premises, the latter being assumptions that are involved in the argumentation - and thus, premises. On the other hand, Jan Svennevig argues that presuppositions also include non-redundant implied premises when he maintains that presuppositions sometimes can hide premises that are not equally obvious or acceptable to the parties in the communication (Svennevig 2001b: 52).

Up to this point, I have described implied premises as logical inference. Presuppositions are semantic or pragmatic inference (Saaed 1987: 101). Whenever presupposition is semantic inference, an implicated sentence will be linguistically encased in another sentence. In the sentence "The Norwegian Language Council (will) have pounded several more handfuls of nails into its own coffin" (example article, Section 5), the contention that "*The Norwegian Language Council has earlier pounded handfuls of nails into its own coffin" is implied by the insertion of the words "several more". I consider calling this a semantic presupposition. We endorse the presupposition on a semantic, rather than a logical, basis. Thus, I feel that Svennevig is mixing levels in the above citation. Premises and presuppositions belong to different types of inference.

Viewed as a presupposition, a pragmatic inference, which I consider calling pragmatic presupposition, is found, for instance, in theme/rheme sequences. The theme denotes what we say something about; the rheme denotes what we say about the theme. The theme is the content element that is mentioned first in a sentence. As a rule, the theme consists of known information while the rheme information is new (Frimann 2004: 204ff). In the example article, Section 4, what is presupposed is the possibility of finding a Norwegian Language Council, which has an annual meeting, and has appointed members who are dealing with something, and that has a professional committee that has made a proposal. This also presupposes what the Norwegian Language Council is, and what its committee is. This is background knowledge that is deduced pragmatically and semantically. The context in a broad sense determines whether the sentence "Today, for the second and final day of the annual general meeting of the Norwegian Language Council, delegates will be dealing with their committee's proposal con- 
cerning the Norwegian spelling of borrowed words, many of them from English" is the answer to the question "What is going to happen?", "When will it happen?" or "Who is going to do it?" The way the sentence stands at the moment, time is focused as the theme. The rheme tells about what is going to happen. By using the abstruse word order - "The delegates of the Norwegian Language Council will be dealing with their professional committee's proposal on Norwegian spelling of borrowed words, most of them from English, today, the second and final day of their annual general meeting" the rheme would have explained when this would happen. The equally abstruse word order - "Their professional committee's proposal for the spelling of borrowed words, most of them from English, will today, on the second and final day of the annual general meeting of the Norwegian Language Council, be dealt with by the appointed members" - would yield a rheme telling who was going to do this.

I have now established the implied premises and presuppositions as subcategories of inference. A third category is implicature.

Svennevig (1995: 108) describes implicature as an implicit message that we deduce. Sigrell writes: Implicature is an implied premise that acts in such a way that it almost suggests a logical character. It is what follows from an utterance, a relation between two statements where one cannot confirm the first and at the same time deny the truthfulness in the second without being guilty of self-contradiction (Sigrell 2001: 284). While presuppositions are implicit facts, implicature is implied correlation. Implicatures communicate what something implies.

Section 13 of the example article - "The teachers who count words and crunch numbers, but do not facilitate an understanding of levels of style, or emphasize that it is important to write well, become just as sour every time they come to hear that is they do and not do" - contains the implicature that the teachers do not achieve their goals. This is what I will call semantic inference - or semantic implicature. What we deduce from the implicature is linguistically constituted in the initial sentence. Anyone who is going to teach good language must communicate an understanding of style or maintain that it is important to write well, if this teacher is going to achieve his or her goal. (In parenthesis it is natural to mention here that redundancy is also a form of semantic inference. This is the reason that the elliptical formulation "come to hear that is they do and not do" can be seen to give meaning.)

For the commentary writer, it is of central importance to get across the implicature that the teachers do not achieve their goal, but in a manner such that it is the reader who makes this deduction. The discursive point in the commentary writer's ethos is whether the contentions derived from the implicature are an adequate description of reality.

In addition, implicatures can constitute pragmatic inference. Here, the implicature is not constituted linguistically in the actual initial sentence, but arises from the context. We have already cited one example of this: simply by mentioning that Sylfest Lomheim is a Francophile the commentary writer demonstrates that he is well-informed. I would call this an example of implicature that emerges by means of pragmatic inference. We could very well use the expression pragmatic implicature. In fact, Stephen Levinson (2000: 168, 243) does distinguish between semantic and pragmatic implicature.

The limits of the genre and genre expectations are essential contextual elements that make implicatures about the ethos of the commentary writer particularly important in commentary articles. Such pragmatic implicatures are what I will call ethosimplicatures. 
Thus, I wish to dissect the concept of inference as follows:

\begin{tabular}{l|llll}
\hline \multicolumn{5}{c}{ Inference } \\
\hline Type & Statistical & Semantic & Logical & Pragmatic \\
\hline Unit & Number & Sentence & Text & Context \\
a Conclusion & Induction & & Deduction & \\
& Testing & & Induction & \\
\hline Premise & Computing & & Abduction & \\
& & Presupposition & Redundant & Presupposition \\
& & Implicature & premises and & Implicature \\
& & Redundancy & conclusions; & Interpretation \\
& & Connotation & Non-redundant & \\
& & & premises and & \\
\hline
\end{tabular}

Dan Sperber and Deirdre Wilson (1995: 236) distinguish between strong and weak implicatures. This distinction corresponds to the division I have made between semantic and pragmatic implicatures, and it corresponds to Grice's distinction between conventional and conversational implicatures (Grice 1975: 45). Sperber and Wilson maintain that the distinction is not absolute, but rather that they are speaking about a continuum. Implicatures can be anchored in both text and context at the same time - some most strongly in the text, and others most strongly in the context. Pragmaticians and semioticians who occupy themselves only with the strongest implicatures have a deficient understanding of verbal communication (Sperber \& Wilson 1995: 201ff).

As a consequence of this view, Sperber and Wilson analyse both tropes and irony as implicature - indeed, the weaker the implicature, the richer the possibilities. In this manner, they depart from the normal way rhetoric handles tropes and irony as special speech categories. The focus is on communication in which the method of expression is both chosen and understood in light of the fact that, right from the beginning, communication is perceived to be relevant by both the sender and the receiver. This principle is called relevance theory and takes its point of departure from Grice's relevance maxim: "Be relevant" (Grice 1975: 46ff). In order to evaluate whether ethos becomes stronger or weaker, one must therefore evaluate how relevant the thing being communicated is.

Sperber and Wilson's approach should open the way, for example, to the fact that literary interpretation must only be understood as the analysis of more or less weak implicatures. However, the receiver must be competent: indeed, the greater the interpretation potential of the implicatures, the greater the responsibility the receiver assumes in order to interpret them, and the more poetic and creative the metaphor. A good creative metaphor with weak implicature opens up many possibilities of context. With the best metaphors the interpreter also transcends the context. Although interpreting metaphors as weak implicatures is initiated by the sender, they are the responsibility of the receiver. Interpretation arises from text and context, and presupposes competence and complicit interaction: "a single expression which has itself been loosely used will determine a very wide range of acceptable weak implicatures" (Sperber \& Wilson 1995: 236ff). This point is worth bearing in mind now as we examine ethos-implicatures in the example article. 


\section{Establishing Ethos through Inference}

The example article contains little in the way of logos argumentation. The following assertions in the example article belong to the category of speech acts called constatives (Searle 1969; Vagle et al. 1993:89):

It so happens that professional circles shut themselves away (Section 2).

Today, for the second and final day of the annual general meeting of the Norwegian Language Council, delegates will be dealing with their professional committee's proposal concerning the Norwegian spelling of borrowed words, most of them from English. This time it is words with 'c', and among the recommendations are 'køpp' equated with 'cup' as in 'cupfinal', 'beiken' side by side with 'bacon', and 'trøkk' for 'truck' (Section 4).

The chairman of the aforementioned body, Professor Helge Sandøy at the University of Bergen, told Aftenposten yesterday that he has calculated that the Norwegianization, that is the introduction of Norwegian spelling for foreign words, ought to be functioning at a level four times higher than its present level [...] This is an arithmetic problem we can look forward to seeing up on the blackboard [...] In her role as Cultural Minister, Åse Kleveland jammed on the brakes when she heard the Norwegian Language Council's proposal to write 'pøbb' for a place where you can get yourself a glass of beer, and the proposal was put on ice $[\ldots]$ We still go on writing 'pub' (Section 8).

The Ministry has thought of closing down the Norwegian Language Council, in any case in its present form. We who sit there have had our mandate period extended until further notice (Section 9).

It has hired a director for the Norwegian Language Council, Sylfest Lomheim [...] Lomheim revealed a glimpse of his thinking yesterday in Dagsnytt 18 [Daily News 18]: 'Because we write chocolate as sjokolade we should write bacon as beiken' (Section 14).

Per Egil Hegge has been appointed to the Norwegian Language Council as representative for the Norwegian Association of Editors and the Norwegian Press Federation (Section 16).

We find the speech act directives (ibid.) in the questions "Why and how is it precisely four? Why not five? Or four and a half?" (Section 8). The rest of the text is composed of evaluations and judgements - mainly realized as speech act evaluatives (Roksvold 2005: 25). Both irony and tropes are used in the evaluations. In the example article, the commentary writer's strategy does not consist of substantiating the evaluative judgements by means of precise reasoning. Instead, by using humorous characterizations he tries to get the readers to laugh maliciously along with him at the bullying of someone who deserves it. By amusing and entertaining the public, one can attract this public to one's own point of view, and thereby secure ethos for oneself. I mention here in passing that Cicero in Book I of De Oratore used the word "delectare (= to amuse, entertain) when speaking about ethos, but he used "conciliare" (= to unite, to win over to oneself) in Book II of De Oratore (Slaattelid 1993: 11-12). "Conciliare" corresponds best with Aristotle's conception of ethos. In the example article, however, ethos-construction is associated with "delectare". 
When the commentary writer explicitly mentions himself in the example article he generally employs self-irony. In Section 5, he stresses that he has no desire for an academic career; in Sections 6 and 8, he flirts with ignorance; in Section 8, he also portrays himself as naïve, and in Sections 13 and 14, he indicates that he is not intelligent. He activates a topos of modesty. By presenting himself as modest in relation to his own qualities he puts across, at least superficially, the impression that he does not have exaggerated lofty thoughts about his own intellectual capacity. This strengthens his ethos. But in its context the statement comes across as ironic. And with this, the message is grasped that indeed the commentary writer has a great intellectual capacity, and because he himself brings up the theme, it appears important for him to get the message across. For him at least it is relevant. In this sense he appears self-centred and intellectually vain, and this does not serve to strengthen ethos. At the same time, this message is softened somewhat by means of irony. And thus he comes across as humorous. He strengthens his ethos by arousing laughter through irony. To arouse laughter is to appeal to people's feelings - consequently pathos.

Hyperbole - exaggeration - is a diagnostic of irony. In Section 14, the irony has been deposited in the hyperbole "mentally crippled". In Section 15, the hyperbole "linguistic bacon soup" is not ironic. It is, however, humorous because it concentrates both the Language Council as a soup council and the activity of cooking up soup, not made from nothing, but rather from "beiken", which is the proposed spelling of "bacon". Thus, it is implied both that the Language Council is hopeless and that the commentary writer is creative and humorous. This can strengthen ethos. The debatable point is how the reader perceives the description in terms of relevance of communication, as the article does not present any grounds for what is so hopeless about the Language Council's proposed spelling of "beiken". With such a demonstration, this characterization would have played a stronger role in ethos-building.

Tropes appeal to pathos through the power of connotations: implications. In Section 5 of the example article, we have "pounded", which in the first instance connotes a powerful noise, and next to that, a sense of dogged persistence. Toiling away persistently without understanding that one is hastening one's own ruin implies stupidity. But this implicature in itself implies that he who exposes such stupidity is wise. Here this implies the commentary writer himself, who thus implicitly supports his ethos - provided that his description of the Language Council's work is perceived as relevant. For readers who do not find the description relevant this is a fallacy of the loaded expression type (Pirie 1987: 112) - and thereby ethos-weakening. Fallacies break with Grice's quality maxim about confining oneself to the truth and not maintaining anything one does not have evidence for (Grice 1975: 46).

In Section 7, we have the numbers trick (Fabricius \& Roksvold 2004: 95) It has not been verified that as many as four million Norwegians are laughing at the Norwegian philologists, but if the commentary writer's vision is shared by so many, then the pointing out of this great fellowship certainly supports his ethos.

The prestige trick (Andersson \& Furberg 1970) is used in the discursive tail (Section 16) and in Section 6 ("I have been a member for four years"). Moreover the photograph of the commentary writer connotes authority.

The commentary writer is ironic over the fallacy of false precision (Pirie 1987: 82) in Section 8. This weakens Sandøy's ethos in the article and strengthens his own.

The fallacy argumentum ad antiquitatem - the old is best - appears between the lines as long as reasonable argumentation, that the spelling of borrowed words ought not to 
be Norwegianized, has not been advanced in an objective manner. It then seems the standpoint is that the spelling should not be changed, because it would then be permanent. This is a pathos argument.

In Section 13, "the teachers" is a generalizing argument (Fabricius \& Roksvold 2004: 96). Here it is even unclear whether the description applies to all teachers of journalism or all the country's teachers of Norwegian, or both the sum total of journalism and Norwegian teachers. On the other hand, it seems clear that the word "journalists" should read "*all journalists" and not "*some journalists". "Young people" can also be read as "*all young people" instead of "*some young people".

When the commentary writer does not make explicit what he refers to, Grice's clarity maxim "Be perspicuous" (Grice 1975: 46) is violated.

All the bad-mouthing and running down of the Language Council, Sandøy, Norwegian philology's professional circles and the teachers is an argumentum ad hominem (Pirie 1987: 94) - it is below the belt, or if you will, a kick in the balls — so long as the critique is not substantiated by factually-based argumentation, but rather is left as a loaded, biased and one-sided account (op. cit.: 112, 126). In Sections 8 and 10, we find comparatively clear examples of argumentum ad hominem: "This is an arithmetic problem we can look forward to seeing chalked up on the blackboard, and which will certainly occur with the cheerful good spirits that always mark the Norwegian Language Council's discourses - at Lysebu this Friday" (Section 8) and "Let us hope that this prolongation is not too long - if I may express my feelings in a manner to which the Norwegian Language Council would have no objections" (Section 10).

We find irrelevant humour (op. cit.: 105) in Section 5 ("and such it is since I am not going to make a career in Norwegian philological circles"), in Section 8 ("Why not five? Or four and a half? [...] the expression bannan was later politely approved as already ripe [...] something in the vicinity of the normal alcohol content percentage for beer") and in Section 14 ("Mussolini who guzzled kianti, for that is how chianti is to be spelled from today").

When in Section 9 the commentary writer writes that the Ministry "has thought of closing down the Norwegian Language Council" ethos is strengthened with the addition "in any case in its present form". Simply on the understanding that the Language Council is to be changed, the commentary writer has managed to keep his point of view intact. This trick is called enclosing or fencing in (op. cit.: 91).

The example article concludes (Section 15) with a quote from Chlorine Ballz: "This is total nonsense. All of it. It's just something we invented." For those who recall the comedy sketch it was taken from, the citation is humorous because the sketch itself was funny. As the conclusion to the example article, it is humorous because we draw the connection between the Soup Council and the Language Council and understand that the characterization of the former should be applied to the latter. But whatever it is that makes the Language Council's proposal idiotic is not elucidated. The analogy is thus not established. The analogy is taken for granted as an argumentum ad populum (op. cit.: 133 ) - the voice of the people (vox populi). But it is possible that we have an analogically wrong conclusion (op. cit.: 19) 


\section{Ethos-Implicatures in the Example Article}

In the foregoing, I have commented on only a few examples that come across as more or less problematic instances of ethos-building in the example article. In what follows below, I have completed the analysis section by section. In the second column of the following table, entitled "What We See", the contents of various passages are reproduced. In the third column "What It Says", I comment on how the content can be understood. The fourth column is devoted to ethos-implicatures. In the final column, I problematize the basis for ethos-establishing in the various passages:

Sec-

Ethos-Establishing

\begin{tabular}{|c|c|c|c|c|}
\hline tion & What We See & What It Says & Ethos-Implicature & Possible Problem \\
\hline 1 & $\begin{array}{l}\text { Deliberate contami- } \\
\text { nation reveals poor } \\
\text { language use. In its } \\
\text { real sense, "bacon" } \\
\text { is fat pork; "beiken" } \\
\text { is fat pork in a } \\
\text { transferred sense }\end{array}$ & $\begin{array}{l}\text { Connotations: } \\
\text { meaningless-ness }\end{array}$ & $\begin{array}{l}\text { The commentary } \\
\text { writer is humorous } \\
\text { and sovereign }\end{array}$ & $\begin{array}{l}\text { How is one meant to } \\
\text { understand the title? }\end{array}$ \\
\hline 2 & $\begin{array}{l}\text { The point of entry } \\
\text { stresses that } \\
\text { Norwegian } \\
\text { philologists are far } \\
\text { distant from reality } \\
\text { and thereby } \\
\text { incompetent }\end{array}$ & $\begin{array}{l}\text { Such is the } \\
\text { correlation }\end{array}$ & $\begin{array}{l}\text { The commentary } \\
\text { writer is clear, } \\
\text { analytical, well- } \\
\text { informed and } \\
\text { competent }\end{array}$ & $\begin{array}{l}\text { Is the correlation } \\
\text { actually such? }\end{array}$ \\
\hline 3 & $\begin{array}{l}\text { Editor Hegge - a } \\
\text { strict and well- } \\
\text { groomed } \\
\text { commentator }\end{array}$ & $\begin{array}{l}\text { The commentary } \\
\text { writer is precise and } \\
\text { serious }\end{array}$ & $\begin{array}{l}\text { Believe the } \\
\text { commentary writer! }\end{array}$ & \\
\hline 4 & $\begin{array}{l}\text { Factual information } \\
\text { on the Language } \\
\text { Council meeting }\end{array}$ & $\begin{array}{l}\text { Such is the proposal. } \\
\text { Prevailing } \\
\text { impartiality }\end{array}$ & $\begin{array}{l}\text { Believe the } \\
\text { commentary writer }\end{array}$ & \\
\hline 5 & $\begin{array}{l}\text { Stupid Language } \\
\text { Council proposal. } \\
\text { Language Council } \\
\text { does not understand } \\
\text { it is digging its own } \\
\text { grave }\end{array}$ & $\begin{array}{l}\text { Commentary writer } \\
\text { is humorous and } \\
\text { plays on false } \\
\text { modesty }\end{array}$ & $\begin{array}{l}\text { The commentary } \\
\text { writer understands } \\
\text { more than the } \\
\text { Language Council }\end{array}$ & $\begin{array}{l}\text { Why is the proposal } \\
\text { so hopeless? How } \\
\text { can the commentary } \\
\text { writer take it for } \\
\text { granted that the } \\
\text { Language Council } \\
\text { understands little? }\end{array}$ \\
\hline 6 & $\begin{array}{l}\text { There is something } \\
\text { wrong with the } \\
\text { Language Council. } \\
\text { The Language } \\
\text { Council believes it is } \\
\text { important to be able } \\
\text { to write "beiken" }\end{array}$ & $\begin{array}{l}\text { Commentary writer } \\
\text { uses self-irony. What } \\
\text { the Language } \\
\text { Council believes is } \\
\text { important is } \\
\text { unimportant }\end{array}$ & $\begin{array}{l}\text { The commentary } \\
\text { writer knows } \\
\text { because he is a } \\
\text { member }\end{array}$ & $\begin{array}{l}\text { Does the } \\
\text { commentary writer's } \\
\text { description hold } \\
\text { true? Does this } \\
\text { apply only to the } \\
\text { commentary writer } \\
\text { who knows because } \\
\text { he is a member? }\end{array}$ \\
\hline 7 & $\begin{array}{l}\text { The Language } \\
\text { Council = "the } \\
\text { Norwegian }\end{array}$ & $\begin{array}{l}\text { The language } \\
\text { Council is laughable }\end{array}$ & $\begin{array}{l}\text { The commentary } \\
\text { writer is the only } \\
\text { member of the }\end{array}$ & $\begin{array}{l}\text { Are the Norwegian } \\
\text { philologists like this? }\end{array}$ \\
\hline
\end{tabular}


Ethos-Establishing (cont.)

Sec-

\begin{tabular}{|c|c|c|c|c|}
\hline tion & What We See & What It Says & Ethos-Implicature & Possible Problem \\
\hline & $\begin{array}{l}\text { philologists' lofty, } \\
\text { self-imposed solitary } \\
\text { confinement". } 4 \\
\text { million are laughing } \\
\text { at the Language } \\
\text { Council }\end{array}$ & & $\begin{array}{l}\text { Language Council } \\
\text { who is not laughable }\end{array}$ & \\
\hline 8 & $\begin{array}{l}\text { Sandøy thinks the } \\
\text { tempo of } \\
\text { Norwegianization } \\
\text { ought to be four } \\
\text { times higher }\end{array}$ & $\begin{array}{l}\text { The commentary } \\
\text { writer is humorous. } \\
\text { Sandøy is laughable } \\
\text { and non-serious. An } \\
\text { intoxicated } \\
\text { Language Council is } \\
\text { out of its mind }\end{array}$ & $\begin{array}{l}\text { The far-sighted } \\
\text { commentary writer } \\
\text { is sharper than } \\
\text { Professor Sandøy }\end{array}$ & $\begin{array}{l}\text { Why has Sandøy } \\
\text { become professor } \\
\text { and not the } \\
\text { commentary writer? }\end{array}$ \\
\hline 9 & $\begin{array}{l}\text { The Language } \\
\text { Council should be } \\
\text { closed down }\end{array}$ & $\begin{array}{l}\text { The Language } \\
\text { Council is not } \\
\text { functioning because } \\
\text { it advances non- } \\
\text { serious proposals }\end{array}$ & $\begin{array}{l}\text { The commentary } \\
\text { writer's view is } \\
\text { shared by the } \\
\text { ministry }\end{array}$ & $\begin{array}{l}\text { Does the ministry } \\
\text { want to close down } \\
\text { the Language } \\
\text { Council on the basis } \\
\text { of Sandøy's } \\
\text { arithmetic? }\end{array}$ \\
\hline 10 & $\begin{array}{l}\text { The Language } \\
\text { Council would have } \\
\text { no objection to a } \\
\text { "lengthy prolonga- } \\
\text { tion" }\end{array}$ & $\begin{array}{l}\text { The Language } \\
\text { Council approves of } \\
\text { language misuse }\end{array}$ & $\begin{array}{l}\text { The only one who } \\
\text { bears arms in } \\
\text { defence of good } \\
\text { language use is the } \\
\text { commentary writer }\end{array}$ & $\begin{array}{l}\text { Is it true that the } \\
\text { Language Council } \\
\text { has nothing against } \\
\text { poor use of } \\
\text { language? Is a } \\
\text { "short prolongation" } \\
\text { inconceivable? }\end{array}$ \\
\hline 11 & $\begin{array}{l}\text { Faculties of } \\
\text { Norwegian are odd } \\
\text { social } \\
\text { anthropological } \\
\text { isolates }\end{array}$ & $\begin{array}{l}\text { Social anthropology } \\
\text { is negative }\end{array}$ & $\begin{array}{l}\text { What the } \\
\text { commentary writer } \\
\text { represents is } \\
\text { positive }\end{array}$ & $\begin{array}{l}\text { Are there such } \\
\text { things as "faculties } \\
\text { of Norwegian"? How } \\
\text { can something } \\
\text { isolated have } \\
\text { influence? }\end{array}$ \\
\hline 12 & $\begin{array}{l}\text { Spelling is } \\
\text { immaterial }\end{array}$ & $\begin{array}{l}\text { There is no dispute } \\
\text { about language. } \\
\text { Language planning } \\
\text { is unnecessary }\end{array}$ & $\begin{array}{l}\text { The commentary } \\
\text { writer knows what } \\
\text { care of language } \\
\text { should look like. } \\
\text { Language variants } \\
\text { other than those of } \\
\text { the commentary } \\
\text { writer should be } \\
\text { ignored }\end{array}$ & $\begin{array}{l}\text { Is the commentary } \\
\text { writer's concept of } \\
\text { language adequate? }\end{array}$ \\
\hline 13 & $\begin{array}{l}\text { Because Norwegian } \\
\text { faculties are simply } \\
\text { toiling away, } \\
\text { journalist students } \\
\text { do not get proper } \\
\text { instruction in } \\
\text { Norwegian. The } \\
\text { teachers are not } \\
\text { disseminating an }\end{array}$ & $\begin{array}{l}\text { Journalist education } \\
\text { is disqualified. The } \\
\text { teachers are } \\
\text { incompetent }\end{array}$ & $\begin{array}{l}\text { The commentary } \\
\text { writer does not have } \\
\text { journalist education } \\
\text { and is therefore } \\
\text { qualified }\end{array}$ & $\begin{array}{l}\text { How can the } \\
\text { commentary writer } \\
\text { know what he writes } \\
\text { concerning journalist } \\
\text { education and } \\
\text { teachers? Which } \\
\text { teachers? What is } \\
\text { the meaning of } \\
\text { "become equally }\end{array}$ \\
\hline
\end{tabular}


Sec-

Ethos-Establishing (cont.)

\begin{tabular}{|c|c|c|c|c|}
\hline ion & Ihat We See & What It Says & Ethos-Implicature & Possible Problem \\
\hline & $\begin{array}{l}\text { understanding of } \\
\text { language style }\end{array}$ & & & $\begin{array}{l}\text { sour every time they } \\
\text { hear that is they do } \\
\text { and not do"? Or is } \\
\text { the commentary } \\
\text { writer not } \\
\text { linguistically } \\
\text { perfect? Is the } \\
\text { commentary writer } \\
\text { truthful? }\end{array}$ \\
\hline 14 & $\begin{array}{l}\text { Newly appointed } \\
\text { Francophile } \\
\text { Language Council } \\
\text { Director Lomheim } \\
\text { will lead a } \\
\text { corporative institu- } \\
\text { tion, and maintains } \\
\text { that the spelling of } \\
\text { "sjokolade" is } \\
\text { relevant to the } \\
\text { spelling "beiken" }\end{array}$ & $\begin{array}{l}\text { Lomheim (all the } \\
\text { same) will not } \\
\text { achieve his goal }\end{array}$ & $\begin{array}{l}\text { The commentary } \\
\text { writer knows better } \\
\text { than Lomheim }\end{array}$ & $\begin{array}{l}\text { What makes the } \\
\text { Language Council } \\
\text { corporative when it } \\
\text { is not a fascist } \\
\text { institution? What is } \\
\text { hopeless about } \\
\text { Lomheim's } \\
\text { example? Does the } \\
\text { Language Council } \\
\text { propose "ought"? }\end{array}$ \\
\hline 15 & $\begin{array}{l}\text { The Norwegian } \\
\text { Language Council is } \\
\text { to be dismantled } 33 \\
\text { years after } \\
\text { WesenSteen's soup } \\
\text { council comedy } \\
\text { sketch }\end{array}$ & $\begin{array}{l}\text { The Norwegian } \\
\text { Language Council = } \\
\text { The Norwegian Soup } \\
\text { Council }\end{array}$ & $\begin{array}{l}\text { By contrast, the } \\
\text { commentary writer } \\
\text { does not tolerate } \\
\text { nonsense }\end{array}$ & $\begin{array}{l}\text { Is it probable that } \\
\text { the Norwegian } \\
\text { Language Council = } \\
\text { the Norwegian Soup } \\
\text { Council? Is the } \\
\text { analogy defensible? } \\
\text { The commentary } \\
\text { writer does not write } \\
\text { "sketch", but "sketsj" } \\
\text { (in Norwegian)! }\end{array}$ \\
\hline 16 & $\begin{array}{l}\text { The commentary } \\
\text { writer represents the } \\
\text { Norwegian Associa- } \\
\text { tion of Editors and } \\
\text { the Norwegian Press } \\
\text { Federation }\end{array}$ & $\begin{array}{l}\text { The representation } \\
\text { from the editorial } \\
\text { and press } \\
\text { organizations is } \\
\text { corporativistic - but } \\
\text { in the present } \\
\text { context this is not } \\
\text { relevant }\end{array}$ & $\begin{array}{l}\text { The commentary } \\
\text { writer is a unique } \\
\text { representative of the } \\
\text { press who } \\
\text { (therefore) here } \\
\text { stands for good } \\
\text { sense }\end{array}$ & $\begin{array}{l}\text { Does the } \\
\text { commentary writer } \\
\text { represent himself or } \\
\text { the press? }\end{array}$ \\
\hline 17 & $\begin{array}{l}\text { Cartoon of Heide } \\
\text { Steen Jr. madly } \\
\text { flailing around in the } \\
\text { Norwegian } \\
\text { Language Council's } \\
\text { soupy stew }\end{array}$ & $\begin{array}{l}\text { The Norwegian } \\
\text { Language Council is } \\
\text { non-serious and is } \\
\text { preoccupied with } \\
\text { nonsense }\end{array}$ & $\begin{array}{l}\text { The commentary } \\
\text { writer is serious. } \\
\text { The commentary } \\
\text { writer knows } \\
\text { language }\end{array}$ & $\begin{array}{l}\text { Is the analogy } \\
\text { probable? }\end{array}$ \\
\hline
\end{tabular}

For the most part, the columns "What We See" and "What It Says" exemplify semantic inference; the columns "Ethos-implicature" and "Possible Problem" in the main exemplify pragmatic inference. Logical inference in the column "What We See" is problematized in the column "Possible problem". 
The analysis of logical inference shows that the example article's method of drawing conclusions is for the most part inductive and that the arguments do not stand up to critical consideration. The analysis of semantic and pragmatic inference shows that the commentary writer chooses pathos arguments in preference to logos arguments. He thus strengthens his ethos only among those who, from the outset, share his point of view. The analysis of ethos-implicature shows that perhaps, at its deepest level, the example article is above all about the commentary writer himself.

The example article breaks with the expectations of the genre that we will be given an insightful, reasoned view of the position taken. The fact that it breaks with the expectations of the genre does not imply that the genre definition is wrong, as my present angle of approach - like that of the commentary writer - has also been inductive. Rightly enough, I have laid stress on reasoning from logos, but I have analysed only one example article. It may be that the rest of the commentary writer's articles resemble this one, but this is not certain. Still less certain is the contention that articles by other commentary writers break the genre expectations the same way this one does. And that, indeed, may be a point.

\section{References}

Andersson, Jan \& Mads Furberg (1970) Språk och påverkan. Stockholm: Aldus/Bonniers.

Barthes, Roland (1969) Mytologier. Rhodos: Copenhagen.

Fabricius, Julie \& Thore Roksvold (2004) Anvendt retorik. Copenhagen: Akademisk forlag.

Frimann, Søren (2004) Kommunikation - text i kontekst. Aalborg: Institut for Kommunikation, Aalborg Universitetsforlag.

Grice, H. Paul (1975) 'Logic and Conversation', in Peter Cole \& Jerry L. Morgan: Syntax and Semantics. Volume 3. New York - San Francisco - London: Academic Press.

Hastrup, Thure (1991) Aristoteles: Retorik. Copenhagen: Museum Copenhagen, University of Copenhagen: Tusculanums forlag.

Levinson, Stephen C. (2000) Presumptive Meanings. Cambridge, MA: The MIT Press.

Lindhardt, Jan (1987) Retorikk. Oslo: Cappelen.

Pirie, Madsen (1987) Språklig manipulering. Oslo: Cappelen.

Reade, W.H.V. (1938) The Problem of Inference. Oxford: Clarendon Press.

Roksvold, Thore (2003) “'Etikk' kommer av 'ethos”, in Rune Ottosen \& Thore Roksvold (ed.) Presseetisk front. Kristiansand: IJ-forlaget.

Roksvold, Thore (2005) Var avisspråket bedre før? Acta Humaniora nr. 224, Unipub, Oslo

Saeed, John I. (1997) Semantics. Oxford: Blackwell.

Sandvik, Margareth (1995) 'Argumentasjonsanalyse', in Jan Svennevig, Margareth Sandvik \& Wenche Vagle: Tilnarminger til tekst. Modeller for språklig tekstanalyse. Oslo: Cappelen.

Searle, John R. (1969) Speech Acts. Cambridge University Press.

Sigrell, Anders (2001) Att övertyga mellan raderna. Åstorp: Rhetor förlag.

Slaattelid, Hermund (1993) Romersk retorikk. Oslo: Det Norske Samlaget.

Sperber, Dan \& Deirdre Wilson (1986) Relevance. Cambridge, MA.:Harvard University Press.

Svennevig, Jan (2001a) 'Abduction as a Methodological Approach to the Study of Spoken Interaction', Norskrift nr. 103. Universitetet i Oslo: Institutt for nordistikk og litteraturvitenskap.

Svennevig, Jan (2001b) Språklig samhandling. Oslo: Cappelen.

Vagle, Wenche, Margareth Sandvik \& Jan Svennevig (1993) Tekst og kontekst. Oslo: Cappelen. 


\section{Appendix}

\section{Alftenpoften}

Kommentar

(Commentary from the Oslo newspaper Aftenposten)

Fat Pork behind Closed Doors

2

It so happens that professional circles shut themselves away because the real world becomes too hard and too difficult. One example of this is the field of Norwegian philology.

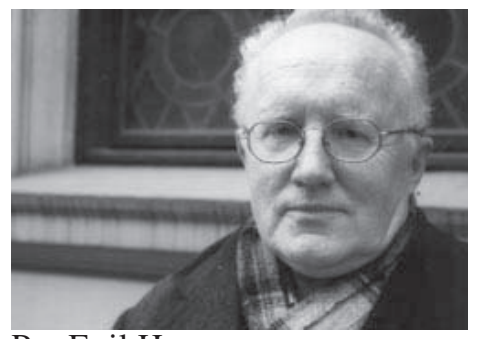

Per Egil Hegge

COMMENTARY

Editor, Aftenposten

\section{4}

Today, for the second and final day of the annual general meeting of the Norwegian Language Council, delegates will be dealing with their professional committee's proposal concerning the Norwegian spelling of borrowed words, most of them from English. This time it is words with 'c', and among the recommendations are ' $\mathrm{k} \emptyset \mathrm{pp}$ ' equated with 'cup' as in 'cupfinal', 'beiken' side by side with 'bacon', and 'trøkk' [which has connotations of a punch or a blow - TR comm.] for 'truck'.

5

If a personal comment were allowed, and it is since I am not going to make a career in Norwegian philological circles - this is nothing more than the preparation of fat pork behind closed doors, fat pork with its foot on the gas, or if you like, just trøkkin' along. But this is actually being approved - and in the course of the day, Friday the $13^{\text {th }}$ of February - the Norwegian Language Council will have pounded several more handfuls of nails into its own coffin, oblivious to what it is doing.

\section{6}

To tell you what is wrong with the Language Council - and I have been a member for four years, so for the first time in 44 years I know what I am writing about - is the fact that its trend-setting members believe that this is what is important, while it does not 
matter if one writes a nuanced or a flat Norwegian, well or badly, elegantly or clumsily. In any case, these things are not important enough to engage the Council's attention.

\section{7}

What has not trickled through the insulation to the Norwegian Language Council's lofty, self-imposed solitary confinement is the fact that this is the way it is making itself a laughing stock for about four million people who are interested in the Norwegian language and in good Norwegian. But this does not affect them in the least. For what is much more important than superficial laughter is their ability to quantify, and accordingly, count up, the inner need:

\section{8}

The chairman of the aforementioned body, Professor Helge Sandøy at the University of Bergen told Aftenposten yesterday that he has calculated that this Norwegianization, that is the introduction of Norwegian spelling for foreign words, ought to be functioning at a level four times higher than its present level. Why and how is it precisely four? Why not five, or four and a half?

\section{Pøbb and Ban[n]an[a]}

This is an arithmetic problem we can look forward to seeing chalked up on the blackboard, and which will certainly occur with the cheerful good spirits that always mark the Norwegian Language Council's discourses - at Lysebu this Friday. In her role as Cultural Minister, Åse Kleveland jammed on the brakes when she heard the Norwegian Language Council's proposal to write 'pøbb' [with the possible connotation of 'pøbel' \{rabble\} - TR comm.] for a place where you can get yourself a glass of beer, and the proposal was put on ice. (But the term 'bannan', instead of the standard 'banan' for 'banana' was politely approved as already ripe.)

We still go on writing 'pub'. If we had written 'pøbb' the tempo of Norwegianization would presumably have been only 3.85 times too low. Or 3.92 perhaps. What do I know? In any case, it would be something in the vicinity of the normal alcohol content percentage for beer.

\section{9}

\section{Shutting Down}

Naturally the question that comes to the fore is this: what does the Ministry intend to do about this? Here we find encouraging messages from the field. The Ministry has thought of closing down the Norwegian Language Council, in any case in its present form. We who sit there have had our mandate period extended until further notice.

\section{0}

Let us hope that this prolongation is not too lengthy - if I may express my feelings in a manner to which the Norwegian Language Council would have no objections.

\section{1}

Because the thinking concerning what is important and not important in Norwegian and in Norwegian teaching takes on the colours of the ideas prevailing in this odd, social anthropological isolate located in faculties of Norwegian around the country. 
One toils away at spelling, while what makes for good language is choosing the right and appropriate words and combining them well.

And the mentality of toiling away seeps through. Journalists get no decent teaching in Norwegian, at least not during their formal education. The teachers who count words and crunch figures, but do not facilitate an understanding of levels of style, or emphasize that it is important to write well, become equally sour every time they hear that is they do and not do. But they do not do anything about it. And young people, who are smarter than we were, come to the editors, but they have only this one question as mental baggage, 'What's the big deal?'

\section{4}

\section{Corporativized}

The Ministry has taken an important step. It has hired a director for the Norwegian Language Council, Sylfest Lomheim, and listeners to the National Radio Commission's programme Språkteigen [The Language Ground] know that he is concerned with the issues raised here. He is also so familiar with Southern Europe (the man is a Francophile) that he knows the Norwegian Language Council's appointments to membership are governed by ideas that Benito Mussolini - who guzzled kianti, for that is how chianti is to be spelled from today - used for founding the corporative state. But Lomheim revealed a glimpse of his thinking yesterday in Dagsnytt 18 [Daily News 18]: 'Because we write chocolate as sjokolade we should write bacon as beiken.' One could become a vegetarian for less.

Today of course there is no advice from any actual fascist institution. But the tolerance towards those of us who are so mentally crippled that we do not see any further than the view that the tempo of Norwegianization should be four times higher, is not great.

\section{5}

This accordingly goes towards leadership liquidation, camouflaged as restructuring, and this is happening about 33 years after Rolv Wesenlund and Harald Heide Steen Jr. broke through all the barriers with their immortal comedy sketch about the Norwegian Soup Council on its trøkk.

Today, that linguistic bacon soup is bubbling away at Lysebu. As Heide Steen Jr., alias Consultant Chlorine Ballz, so aptly puts it: "This is total nonsense. All of it. It's just something we invented."

16

Per Egil Hegge has been appointed to the Norwegian Language Council as representative for the Norwegian Association of Editors and the Norwegian Press Federation.

17

[The sketch where Harald Heide Steen Jr. as Chlorine Ballz (more correctly 'Klorin') is flailing around in a soupy stew called 'Norwegian Language Council'.] 